\title{
Pengaruh Kebijakan Dividen Terhadap Kepemilikan Individual Dan Kepemilikan Institusional Dengan Perubahan Peraturan Perpajakan Sebagai Variabel Pemoderasi
}

\author{
Sabrina Kartikasari dan Mienati Somya Lasmana \\ Universitas Airlangga Surabaya \\ Email: sabrina.kartikasari@yahoo.com,msl_feunair@yahoo.com
}

\begin{abstract}
ABSTRAK
Penelitian ini bertujuan untuk menguji pengaruh kebijakan dividen terhadap kepemilikan individual dan institusional dengan perubahan Peraturan Perpajakan sebagai variabel pemoderasi. Pengujian dilakukan dengan teknik moderated regression analysis (MRA), menggunakan sampel 45 perusahaan yang terdaftar di BEI periode 2007-2010. Hasil penelitian ini menunjukkan bahwa kebijakan dividen berpengaruh positif tetapi tidak signifikan terhadap kepemilikan individual. Namun ketika dimoderasi dengan perubahan Peraturan Perpajakan berupa penurunan dan penyederhanaan tarif pajak atas dividen yang diterima orang pribadi dalam negeri sesuai UU No.36/2009, PP No.19/2009 dan PMK No.111/PMK.03/2010, hasilnya berpengaruh positif dan signifikan. Berbeda dengan kepemilikan institusional yang justru dipengaruhi secara negatif dan signifikan oleh kebijakan dividen baik sebelum dan sesudah dimoderasi oleh Perubahan Peraturan Perpajakan.
\end{abstract}

Kata Kunci: Pajak Penghasilan atas dividen, kebijakan dividen, kepemilikan individual, kepemilikan institusional.

\begin{abstract}
This research purports to examine the effect of the dividend policy on individual and institutional ownership with the change on tax regulation as a moderating variable. Examination was done using moderated regression analysis (MRA), using a sample of 45 companies that listed on the BEI for the period of 2007-2010. The result of this study indicates that the dividend policy has a positive but not significant effect on individual ownership. However, if it is moderated by changes in taxation regulation in the form of reduction and simplification of the tax rate on dividend income received by an individual within the country in accordance with Law No.36/2009, Government Regulation No.19/2009 and PMK No.111/PMK.03/2010, the result is positive and significant. By contrast, the institutional ownership is negatively and significantly affected by dividend policy before as well as after it is moderated by changes in taxation regulation.
\end{abstract}

Keywords: Income Tax article for dividend, dividend policy, individual ownership, institutional ownership.

\section{PENDAHULUAN}

Kondisi yang dicapai pasca krisis ekonomi global 2008 sekarang ini tidak lepas dari upaya pemerintah dalam menarik minat investor sehingga menanamkan modalnya kembali di Indonesia. Mengingat faktor penghambat investasi terbesar adalah sistem perpajakan yang rumit dan sulit (Daya Saing Kritis Tanpa Perbaikan 2006), sehingga upaya utama yang dilakukan oleh pemerintah untuk mengatasinya adalah dengan tax policy and administration reform, yakni UU Nomor 36 Tahun 2008 yang merupakan perubahan keempat dari UU Nomor 7 Tahun 1983 
tentang Pajak Penghasilan (selanjutnya disebut UU $\mathrm{PPh}$ ) yang mulai diberlakukan pada tahun 2009. Dalam Pasal 17 ayat (2c) UU PPh memunculkan ketentuan baru berupa tarif pemotongan Pajak Penghasilan maksimal sebesar $10 \%$ dan bersifat final atas dividen yang dibagikan kepada Wajib Pajak orang pribadi dalam negeri, yang secara lebih lanjut diatur dalam Peraturan Pemerintah Nomor 19 tahun 2009 dan Peraturan Menteri Keuangan Nomor 111/PMK.03/2010. Sebelum berlakunya UU Nomor 36 Tahun 2008, dividen yang diterima oleh Wajib Pajak orang pribadi ini menjadi objek $\mathrm{PPh}$ Pasal 23 dengan tarif $15 \%$ tidak final. Sedangkan dividen yang diterima oleh Wajib Pajak badan dalam negeri tidak mengalami perubahan yang signifikan, tetap menjadi objek PPh Pasal 23 dengan tarif 15\% tidak final. Kemudian, kepemilikan institusional yang memiliki penyertaan $25 \%$ atau lebih ketika mendapat dividen dikecualikan dari pemungutan pajak penghasilan. Penurunan dan penyederhanaan tarif atas pemajakan dividen tersebut diharapkan dapat menarik investor domestik maupun investor asing untuk menanamkan modalnya kembali di Indonesia.

Menerbitkan saham merupakan salah satu pilihan perusahaan ketika memutuskan untuk melakukan pendanaan perusahaan, karena saham menawarkan tingkat keuntungan yang menarik di mata investor. Potensi keuntungan dari saham yang diperoleh ketika berinvestasi di pasar modal adalah pembagian dividen dan capital gain. Capital gain adalah keuntungan yang diperoleh dari penjualan aktiva tetap atau selisih harga jual dan harga beli surat berharga (Sartono 2001:483). Sedangkan dividen menurut Norr (1982: 71), adalah 'The amount of the corporation's earnings and profit which the directors (or other appropriate organs of corporation) periodically determine shall be dividend prorata among the shareholder."

Alokasi penentuan laba ditahan dan pembayaran dividen merupakan aspek utama dalam kebijakan dividen (Horne 2012). Kebijakan tersebut menimbulkan dua kepentingan yang saling berlawanan dan harus dipenuhi, yaitu antara tanggung jawab perusahaan kepada shareholder melalui pembayaran dividen dan mempertahankan kelangsungan hidup perusahaan dengan sumber pembiayaan melalui laba ditahan. Menurut teori Clientele Effect, kebijakan dividen yang dapat diukur dengan dividend per share (DPS) ditujukan untuk memenuhi kebutuhan segmen investor tertentu (Hanafi 2004). Sehingga masing-masing kelompok investor memiliki preferensi berbeda terhadap kebijakan dividen perusahaan. Kelompok investor yang menganggap dividen sebagai pendapatan yang pasti (the bird in the hand) akan menuntut pembayaran dividen. Sedangkan untuk kelompok investor yang muncul akibat perbedaan pajak (Tax Differentiation Theory) akan menghindari pembayaran dividen jika tarif pajaknya tinggi dan cenderung memilih pendapatan dari capital gain karena pengenaan tarif pajaknya cenderung lebih rendah, yakni sebesar $0,1 \%$ dari jumlah bruto nilai transaksi penjualan, kecuali bagi pemegang saham pendiri yang dikenakan tarif tambahan sebesar $5 \%$ dari jumlah bruto nilai transaksi penjualan dan dikenakan secara final, yang secara lebih lanjut diatur dalam Peraturan Pemerintah Nomor 41 Tahun 1994 jo. Peraturan Pemerintah Nomor 14 Tahun 1997. Berbeda dengan Miller dan Modigliani (1961) yang meyakini bahwa pembayaran dividen bersifat irrelevant (Irrelevancy Dividend Theory), karena tidak dapat mempengaruhi nilai perusahaan dan harga saham. Dalam merumuskan teori ini, diasumsikan suatu pasar yang sempurna (tanpa pajak dan biaya kebangkrutan), investor bersifat rasional, dan adanya kepastian yang sempurna (perfect certainty).

Kepemilikan saham oleh investor umumnya dibagi menjadi dua jenis, yaitu kepemilikan individual dan institusional (CPA Institute 2007). Investor individual merupakan investor yang melakukan transaksi jual beli sekuritas dalam hal ini termasuk saham untuk kepentingan individu sendiri. (Scott 2003: 199). Berikutnya, Scott (2003: 191) mendefinisikan kepemilikan institusional sebagai entitas yang melakukan kegiatan investasi dalam jumlah besar di pasar sekuritas termasuk di dalamnya saham. Kepemilikan institusional dalam hal ini dapat berupa perusahaan asuransi, perusahaan investasi, dana pensiun, ataupun perusahaan lainnya. Kepemilikan institusional merupakan pemegang saham mayoritas yang dapat mengurangi masalah agensi dalam perusahaan. Hal ini disebabkan karena jumlah kepemilikan investor institusi yang tidak sedikit dan merupakan dana milik beberapa investor individu (masyarakat) sehingga menyebabkan investor institusi akan lebih berhati-hati dan memberikan pengawasan yang lebih ketat terhadap perilaku manajemen yang tidak sejalan dengan kepentingan pemegang saham (opportunistic).

Sponholtz (2005) menyatakan bahwa dividen dapat dijadikan alat untuk meminimumkan jumlah free cash flow untuk manajemen. Berbeda halnya dengan Jain (2007) menemukan bahwa investor institusi lebih menyukai perusahaan yang membagikan dividen dalam skala kecil karena investor institusi beranggapan bahwa dengan 
adanya pembagian dividen, manajer perusahaan dianggap tidak mampu melihat peluang-peluang investasi yang menguntungkan. Brennan (1990) menyatakan bahwa investor individu lebih menyukai perusahaan yang membayar dividen rendah, bahkan tidak sama sekali, sepanjang pengenaan tarif pajak dividen tinggi. Namun keputusan perusahaan untuk membayar dividen yang rendah akan menimbulkan pandangan dari pihak eksternal bahwa profitabilitas perusahaan buruk, sehingga akan berdampak pada menurunnya harga saham dan penurunan nilai dari perusahaan (teori signaling hipotesis). Sehingga dapat disimpulkan bahwa preferensi kebijakan dividen dapat dipengaruhi oleh faktor pajak (tax incentives) dan non-pajak (non-tax incentives).

Tujuan penelitian adalah untuk menguji bagaimana pengaruh kebijakan dividen terhadap kepemilikan individual dan kepemilikan institusional pada perusahaan yang terdaftar di BEI periode tahun 2007-2010, serta menguji apakah perubahan peraturan perpajakan memoderasi pengaruh kebijakan dividen terhadap kepemilikan individual dan kepemilikan institusional pada perusahaan yang terdaftar di BEI periode tahun $2007-2010$.

\section{Hipotesis}

Nurwulandari (2003) menyatakan bahwa investor individu cenderung berusaha untuk mendapatkan haknya berupa dividen yang dibagikan oleh perusahaan daripada menginvestasikan kembali laba yang diperoleh perusahaan, karena mereka tidak merasakan adanya kepastian bahwa pihak manajemen tidak akan bertindak curang dengan mementingkan kepentingan pribadi dan mengabaikan nilai dari perusahaan itu sendiri. Berdasarkan teori signaling hypothesis yang dikemukakan oleh Litzenberger dan Ramaswamy (1979), keputusan perusahaan untuk membayar dividen yang rendah akan menimbulkan pandangan dari pihak eksternal bahwa profitabilitas perusahaan buruk, sehingga akan berdampak pada menurunnya harga saham dan penurunan nilai dari perusahaan. Sesuai dengan penelitian yang dilakukan oleh Nurwulandari (2003) dan Jain (2007) yang menghasikan kesimpulan bahwa kepemilikan saham oleh individu lebih menyukai perusahaan yang membayar dividen yang tinggi. Sehingga hipotesis dalam penelitian ini adalah:

H1: Kebijakan dividen berpengaruh positif terhadap kepemilikan individual

Kepemilikan institusional umumnya merupakan pemegang saham terbesar, sehingga memiliki sumber daya yang lebih dalam menentukan keputusan perusahaan. Selain itu, kepemilikan investor institusi merupakan dana yang dimiliki beberapa investor individu, sehingga memiliki motivasi yang kuat untuk dapat berperan sebagai agen pengawas yang efektif untuk mengurangi agency problem dalam mengendalikan perilaku oportunistik manajer (Bathala et al. 1994). Sehingga dengan tingginya tingkat kepemilikan institusional, dapat mengurangi agency cost dan memungkinkan perusahaan membagikan dividen dalam jumlah yang rendah (Dewi 2008). Ditinjau dari aspek perpajakan, kepemilikan institusional merupakan higher-taxed institutional investor, sehingga investor institusional cenderung tidak menyukai pembayaran dividen yang tinggi. Investor institusi beranggapan bahwa dengan adanya pembagian dividen, manajer perusahaan dianggap tidak mampu melihat peluang-peluang investasi yang menguntungkan (Jain 2007). Sejalan dengan penelitian yang dilakukan oleh Jain (2007) dan Dewi (2008), menunjukkan bahwa kepemilikan institusional cenderung menginginkan dividen dalam jumlah yang relatif kecil bahkan tidak sama sekali. Sehingga hipotesis dalam penelitian ini adalah:

H2: Kebijakan dividen berpengaruh negatif terhadap kepemilikan institusional

Menurut penelitian yang dilakukan oleh $\mathrm{Wu}$ (1996) dan Korkeamaki et al. (2010), Reformasi Pajak melalui perubahan tarif pajak telah memberikan dampak positif pada kebijakan dividen yang selanjutnya berpengaruh terhadap tingkat kepemilikan saham secara keseluruhan. Begitupula dengan hasil penelitian yang dilakukan oleh Zulaikah (2012) yang menunjukkan bahwa penurunan tarif pajak penghasilan dividen wajib pajak orang pribadi dalam negeri memoderasi pengaruh kepemilikan manajerial terhadap peningkatan kebijakan pembayaran dividen perusahaan. Hal ini menimbulkan pertanyaan apakah perubahan peraturan perpajakan tersebut juga memoderasi preferensi investor individual untuk menginvestasikan sahamnya pada perusahaan yang membagikan dividen dalam jumlah yang cenderung meningkat. Sejalan dengan penelitian yang dilakukan oleh Wu (1996), Korkeamaki et al. (2010), dan Zulaikah (2012), maka hipotesis dalam penelitian ini adalah:

H3: Perubahan Peraturan Perpajakan memoderasi pengaruh kebijakan dividen terhadap kepemilikan individual.

Mengingat pengenaan pajak atas penghasilan berupa dividen di Indonesia dibagi menjadi dua, yakni Wajib Pajak orang pribadi dan Wajib Pajak badan, sehingga dengan adanya tax shield ini dapat menimbulkan pertanyaan, apakah hal ini 
berpengaruh terhadap preferensi kepemilikan saham institusional untuk mengalihkan kepemilikannya dalam bentuk kepemilikan individual sehingga dapat meminimalkan pengenaan pajaknya (tax planning). Sesuai dengan penelitian yang dilakukan oleh Korkeamaki et al. (2010), Wu (1996), Chang dan Rhee (1990) bahwa perubahan Peraturan Perpajakan (tax reform) berpengaruh terhadap kebijakan dividen yang ditunjukkan dengan perubahan jumlah kepemilikan saham. Berdasarkan uraian diatas, maka hipotesisnya adalah:

H4: Perubahan Peraturan Perpajakan memoderasi pengaruh kebijakan dividen terhadap kepemilikan institusional.

\section{METODE PENELITIAN}

\section{Model Penelitian dan Teknik Analisis}

Model penelitian ini adalah untuk mengetahui pengaruh kebijakan dividen terhadap kepemilikan individual dan kepemilikan institusional. Oleh karena itu, digunakan teknik analisis regresi linier sederhana dengan formula sebagai berikut:

$$
\begin{aligned}
& \text { INDIV }=a+\beta_{1} \text { DPS } \\
& \text { INST }=a+\beta_{1} \text { DPS }
\end{aligned}
$$

Model penelitian ini adalah untuk mengetahui pengaruh kebijakan dividen terhadap kepemilikan individual dan kepemilikan institusional dengan Perubahan Peraturan Perpajakan sebagai variabel pemoderasi. Oleh karena itu, digunakan teknik analisis regresi linier interaksi (Moderated Regression Analysis-MRA) dengan formula sebagai berikut:

$$
\begin{aligned}
& \text { INDIV }=a+\beta_{1} \text { DPS }+\beta_{2} \text { DPS*DUMTAX }+e \\
& \text { INST }=a+\beta_{1} \text { DPS }+\beta_{2} \text { DPS*DUMTAX }+e
\end{aligned}
$$

Dimana:

INDIV $=$ Kepemilikan Individual

INST $\quad=$ Kepemilikan Institusional

$\mathrm{a}=$ Intercept persamaan regresi

$B_{1} b_{2} \quad=$ Koefisien regresi

DPS $\quad=$ Kebijakan Dividen (Dividend per Share)

DUMTAX = Dummy Perubahan Peraturan Pajak

e $\quad=$ Error/ variabel pengganggu

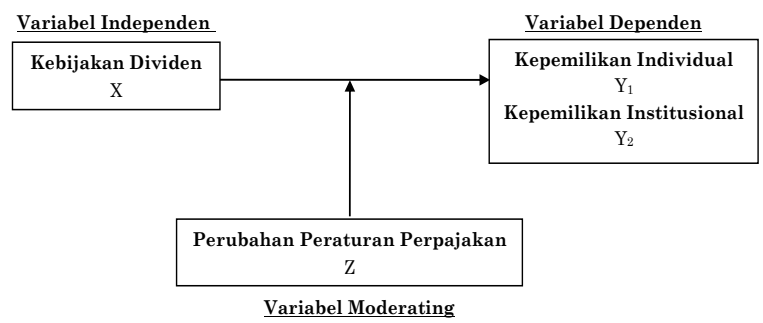

\begin{tabular}{|c|c|c|c|}
\hline Variabel & Indikator & $\begin{array}{c}\text { Tingkat } \\
\text { Pengukuran }\end{array}$ & Skala \\
\hline \multirow{2}{*}{$\begin{array}{c}\text { Kebijakan } \\
\text { Dividen } \\
\text { (DPS) } \\
\end{array}$} & \multirow{2}{*}{$\begin{array}{l}\text { - Dividend per } \\
\text { Share }\end{array}$} & \multirow{2}{*}{$D P S=\frac{\text { DividenTunai }}{\text { Jumlah Saham Beredar }}$} & \multirow[t]{2}{*}{ Rasio } \\
\hline & & & \\
\hline $\begin{array}{l}\text { Kepe- } \\
\text { milikan }\end{array}$ & - Jumlah & & Rasio \\
\hline $\begin{array}{l}\text { Individual } \\
\text { (INDIV) }\end{array}$ & $\begin{array}{l}\text { Individual } \\
\text { - Jumlah Saham } \\
\text { Beredar }\end{array}$ & INDIV $=\frac{\text { Jumlah Kepemilikan Individual }}{\text { Jumlah Saham Beredar }}$ & \\
\hline $\begin{array}{l}\text { Kepe- } \\
\text { milikan } \\
\text { Institusional } \\
\text { (INST) }\end{array}$ & $\begin{array}{l}\text { - Jumlah } \\
\text { Kepemilikan } \\
\text { Institusional } \\
\text { - Jumlah Saham } \\
\text { Beredar }\end{array}$ & INST $=\frac{\text { Jumlah Kepemilikan Individual }}{\text { Jumlah Saham Beredar }}$ & Rasio \\
\hline $\begin{array}{l}\text { Perubahan } \\
\text { Peraturan } \\
\text { Perpajakan } \\
\text { (DUMTAX) }\end{array}$ & $\begin{array}{l}\text { - Sebelum } \\
\text { Perubahan } \\
\text { Peraturan Pajak } \\
\text { - Setelah } \\
\text { Perubahan } \\
\text { Peraturan Pajak } \\
\end{array}$ & $\begin{aligned}-0= & \text { Sebelum } \\
& \text { Perubahan } \\
& \text { Peraturan Pajak } \\
-1= & \text { Setelah } \\
& \text { Perubahan } \\
& \text { Peraturan Pajak }\end{aligned}$ & $\begin{array}{c}\text { Nomin } \\
\text { al }\end{array}$ \\
\hline
\end{tabular}

Gambar 1. Kerangka Konseptual Penelitian
Tabel 1. Definisi Operasional dan Pengukuran Variabel

Sumber: Diolah penulis

Berdasarkan objek dan tujuan penelitian maka digunakan pendekatan kuantitatif asosiatif data sekunder. Populasi yang diambil dalam penelitian ini adalah semua perusahaan yang terdaftar di Bursa Efek Indonesia tahun 2007 sampai dengan 2010. Pengumpulan data dilakukan secara panel data (cross section - time series). Sampel ditentukan dengan menggunakan metode purposive sampling (non-random sampling) yaitu pengambilan sampel yang didasarkan pada pertimbangan untuk menyesuaikan diri dengan beberapa kriteria penelitian agar dapat meningkatkan ketepatan sampel (Cooper and Emory 1995). Kriteria sampel yang digunakan adalah perusahaan yang terdaftar di BEI yang mempublikasikan laporan keuangan tahunan, tidak pernah mengalami delisting, tahun fiskal laporan keuangan perusahaan berakhir pada bulan Desember, membagikan dividen tunai dan yang ada kepemilikan individual serta institusionalnya. Sehingga diperoleh jumlah sampel yang akan diteliti sebanyak 45 perusahaan, data terdapat pada Table 2 .

\section{HASIL PENELITIAN DAN PEMBAHASAN}

\section{Statistik Deskriptif}

Kebijakan dividen menunjukkan besarnya laba perusahaan (Earning After Tax - EAT) yang dialokasikan kepada pemegang saham dalam bentuk dividen yang dalam penelitian ini diproxykan dengan dividend per share (DPS). Untuk mengetahui perubahan jumlah dividen yang dibayarkan oleh perusahaan tiap tahun, maka dalam perhitungannya digunakan relative dividend per share ( $\triangle \mathrm{DPS})$. Nilai standar deviasi 
Tabel 2. Daftar Perusahaan Sampel

\begin{tabular}{|c|c|c|c|c|}
\hline No. & Sektor Industri & Sub Sektor Industri & Nama Perusahaan & Kode \\
\hline \multirow[t]{3}{*}{1.} & Pertanian & Perkebunan & PT Bakrie Sumatra Plantations, Tbk & UNSP \\
\hline & & & PT Tunas Baru Lampung, Tbk & TBLA \\
\hline & & Peternakan & PT Cipendawa, Tbk & CPDW \\
\hline \multirow[t]{4}{*}{2.} & Pertambangan & Batubara & PT Bumi Resources, Tbk & BUMI \\
\hline & & & PT Tambang Batu Bara Bukit Asam, Tbk & PTBA \\
\hline & & Minyak Bumi dan Gas Alam & PT Radiant Utama Interinsco, Tbk & RUIS \\
\hline & & Besi dan Mineral & PT International Nickel Indonesia, Tbk & INCO \\
\hline \multirow[t]{6}{*}{3.} & Dasar dan Kimia & $\begin{array}{l}\text { Logam dan Produk Lainnya yang } \\
\text { Berkaitan }\end{array}$ & PT Citra Tubindo, Tbk & CTBN \\
\hline & & Kimia & PT Budi Acid Jaya, Tbk & BUDI \\
\hline & & & PT Ekadharma International, Tbk & EKAD \\
\hline & & & PT Sorini Agro Asia Corporindo & SOBI \\
\hline & & Plastik dan Kemasan & PT Champion Pasifik Indonesia, Tbk & IGAR \\
\hline & & & PT Trias Sentosa, Tbk & TRST \\
\hline \multirow[t]{2}{*}{4.} & Aneka Industri & Otomotif dan Komponennya & PT Astra Otoparts, Tbk & AUTO \\
\hline & & & PT Selamat Sempurna, Tbk & SMSM \\
\hline \multirow[t]{6}{*}{5.} & Barang & Makanan dan Minuman & PT Aqua Golden, Tbk & AQUA \\
\hline & Konsumsi & Rokok & PT Gudang Garam, Tbk & GGRM \\
\hline & & & PT HM Sampoerna, Tbk & HMSP \\
\hline & & Farmasi & PT Kalbe Farma, Tbk & $\mathrm{KLBF}$ \\
\hline & & & PT Tempo Scan Pacific, Tbk & TSPC \\
\hline & & Rumah Tangga & PT Mandom Indonesia, Tbk & TCID \\
\hline \multirow[t]{4}{*}{6.} & Property, Real & Properti dan Real Estate & PT Jaya Real Property, Tbk & JRPT \\
\hline & Estate, dan & & PT Summarecon Agung, Tbk & SMRA \\
\hline & Bangunan & Bangunan Konstruksi & PT Adhi Karya (Persero), Tbk & $\mathrm{ADHI}$ \\
\hline & Konstruksi & & PT Total Bangun Persada, Tbk & TOTL \\
\hline \multirow[t]{2}{*}{7.} & Infrastruktur, & Transportasi & PT Berlian Laju Tanker, Tbk & BLTA \\
\hline & $\begin{array}{l}\text { Utilitas, dan } \\
\text { Transportasi }\end{array}$ & & PT Samudera Indonesia & SMDR \\
\hline \multirow[t]{7}{*}{8.} & Keuangan & Bank & PT Bank Negara Indonesia, Tbk & BBNI \\
\hline & & Institusi Keuangan & PT Adira Dinamika Multifinance, Tbk & $\mathrm{ADMF}$ \\
\hline & & Perusahaan Sekuritas & PT Kresna Graha Sekurindo, Tbk & KREN \\
\hline & & & PT Panin Sekuritas, Tbk & PANS \\
\hline & & & PT Trimegah Securities, Tbk & TRIM \\
\hline & & Asuransi & PT Asuransi Ramayana, Tbk & ASRM \\
\hline & & & PT Maskapai Reasuransi Indonesia, Tbk & MREI \\
\hline \multirow[t]{12}{*}{9.} & Perdagangan, & Perdagangan Besar (Barang & PT AKR Corporindo, Tbk & AKRA \\
\hline & Jasa, dan & Tahan Lama dan Tidak Tahan & PT Colorpak Indonesia, Tbk & CLPI \\
\hline & Investasi & Lama) & PT Enseval Putera Megatrading & EPMT \\
\hline & & & PT Tigaraksa Satria & TGKA \\
\hline & & & PT Tunas Ridean, Tbk & TURI \\
\hline & & Perdagangan Eceran & PT Ace Hardware, Tbk & ACES \\
\hline & & & PT Ramayana Lestari Sentosa, Tbk & RALS \\
\hline & & Restoran, Hotel, dan Pariwisata & PT Fast Food Indonesia, Tbk & FAST \\
\hline & & Periklanan, Percetakan, dan & & \\
\hline & & Media & PT Fortune Indonesia, Tbk & FORU \\
\hline & & Perusahaan Investasi & PT Surya Citra Media, Tbk & SCMA \\
\hline & & & PT Pool Advista Indonesia, Tbk & POOL \\
\hline
\end{tabular}

Sumber: Laporan Keuangan, diolah

yang relatif tinggi, yaitu sebesar 2,08 mencerminkan adanya variasi yang cukup besar dari kebijakan dividen yang dibayarkan oleh perusahaan yang terdaftar di BEI periode tahun 2007-2010. Kepemilikan individual merupakan prosentase jumlah kepemilikan saham individu (orang pribadi) dibandingkan dengan jumlah kepemilikan saham keseluruhan, yang menunjukkan besarnya proporsi kepemilikan saham indivi- dual di perusahaan tersebut. Sedangkan kepemilikan institusional merupakan prosentase jumlah kepemilikan saham institusi (badan) dibandingkan dengan jumlah kepemilikan saham keseluruhan, yang menunjukkan besarnya proporsi kepemilikan saham institusional di perusahaan tersebut. Nilai standar deviasi yang relatif cukup rendah, yakni 24,53\% untuk kepemilikan individu dan 17,95\% untuk institusi, mencerminkan tidak 
Tabel 3. Deskripsi Statistik

\begin{tabular}{lccccc}
\hline \multicolumn{1}{c}{ Variabel } & N & Minimum & Maksimum & Mean & $\begin{array}{c}\text { Standar } \\
\text { Deviation }\end{array}$ \\
\hline Kebijakan Dividen & 119 & $-0,990000$ & 16,400000 & 0,70252101 & 2,082588114 \\
Kepemilikan Individual & 99 & $-0,900000$ & 0,836338 & $-0,02470541$ & 0,245277254 \\
Kepemilikan Institusional & 74 & $-0,720000$ & 0,793400 & $-0,00125311$ & 0,179466133 \\
Perubahan Peraturan & & & & & 0,473 \\
Perpajakan & 135 & 0 & 1 & & \\
Valid N (listwise) & 64 & & & & \\
\hline
\end{tabular}

Sumber: Data diolah

Tabel 4. Tarif Pajak Dividen yang Diterima oleh Wajib Pajak Orang Pribadi Dalam Negeri

\begin{tabular}{cccc}
\hline \multicolumn{2}{c}{ UU No. 17 Tahun 2000 } & UU No. 36 Tahun 2008 \\
\hline Tarif & Sifat Pengenaan Pajak & Tarif & Sifat Pengenaan Pajak Atas Dividen \\
Pajak & Atas Dividen & Pajak & \\
$15 \%$ & PPh Witholding Tax & $10 \%$ & PPh Final \\
\hline
\end{tabular}

Sumber: Undang - undang Nomor 17 Tahun 2000 dan Undang - undang Nomor 36 Tahun 2008.

adanya perubahan yang terlalu besar komposisi dari kepemilikan individual dan institusional pada perusahaan yang terdaftar di BEI selama periode tahun $2007-2010$.

Variabel Perubahan Peraturan Perpajakan digunakan untuk mengukur perubahan peraturan perpajakan berupa penurunan dan penyederhanaan tarif penghasilan atas dividen yang diterima oleh pemegang saham individual. Variabel Perubahan Peraturan Perpajakan bersifat kualitatif, sehingga untuk mengkuantitatifkannya adalah dengan membangun variabel dummy dengan cara memberi nilai 1 atau 0. Angka 0 menunjukkan sebelum perubahan Peraturan Perpajakan (UU Nomor 17 Tahun 2000), sedangkan angka 1 menunjukkan setelah perubahan Peraturan Perpajakan (UU Nomor 36 Tahun 2008) (Tabel 4).

\section{Uji Asumsi Klasik}

Untuk memperoleh model regresi terbaik dan memenuhi kriteria BLUE (Best Linier Unbiased Estimator), maka harus dilakukan uji asumsi klasik terlebih dahulu yang terdiri dari 4 pengujian: uji normalitas, uji multikolinieritas, uji autokorelasi, dan uji heteroskedastisitas. Salah satu cara untuk melihat normalitas residual adalah dengan melihat grafik normal probability plot dan grafik histogram. Setelah dilakukan deteksi outlier menggunakan case diagnostics sebanyak 6 kali untuk variabel kepemilikan individual dan 7 kali untuk variabel kepemilikan institusional, maka didapatkan grafik normal probability plot dan grafik histogram yang telah memenuhi asumsi normalitas.

Pengujian dengan menggunakan MRA sangat rawan terkena asumsi multikolinieritas.
Untuk mengetahui ada tidaknya gejala ini digunakan indikasi nilai VIF (Varian Inflation Factor) dan nilai tolerance. Hair (2006) menyebutkan angka toleransi VIF untuk terhindar dari gejala multikolinieritas ini $\leq 10$ dengan nilai tolerance $\geq 0,1$. Dari uji multikolinieritas yang dilakukan, terbukti bahwa variabel kepemilikan individual dan institusional bebas dari gejala multikolinieritas.

Selanjutnya dilakukan uji autokorelasi untuk mendeteksi ada tidaknya korelasi antara unsur gangguan dalam penelitian. Dari Durbin-Watson test yang dilakukan, diperoleh nilai D-W 1,868 untuk variabel kepemilikan individual dan 2,197 untuk variabel kepemilikan institusional. Angka ini berada diantara 1,5 $<\mathrm{D} . \mathrm{W}<2,5$, sehingga dapat disimpulkan bahwa tidak terjadi autokorelasi pada kedua variabel Y tersebut.

Gejala heteroskedastisitas dideteksi dengan menggunakan grafik plot (scatterplot). Dari hasil grafik scatterplot diketahui bahwa terjadi heterokedastisitas dari sampel yang digunakan dalam penelitian ini. Cara untuk mengatasi hal tersebut adalah dengan mengeluarkan data outlier yang menyebabkan gejala heterokedastisitas terjadi. Setelah menghilangkan data outlier maka diperoleh hasil data yang bebas dari gejala heterokedastisitas.

\section{Uji Hipotesis}

Penelitian ini mempunyai empat hipotesis, pengujian hipotesis pertama dan kedua yaitu untuk menguji pengaruh kebijakan dividen terhadap kepemilikan individual dan institusional menggunakan uji regresi linier sederhana. Sedangkan pengujian hipotesis ketiga dan 
Tabel 5. Hasil Uji Regresi Linier Sederhana X terhadap $\mathrm{Y}_{1}$ dan $\mathrm{Y}_{2}$

\begin{tabular}{|c|c|c|c|c|c|c|c|c|}
\hline Variabel & $\begin{array}{c}\text { Koefisien } \\
\text { Regresi }\end{array}$ & Beta & $\mathbf{t}$ & Sig. & $\begin{array}{c}\text { Koefisien } \\
\text { Regresi }\end{array}$ & Beta & $\mathbf{t}$ & Sig. \\
\hline Konstanta & $-0,013$ & & $-0,600$ & 0,550 & 0,005 & & 0,369 & 0,713 \\
\hline Kebijakan Dividen & 0,006 & 0,009 & 0,672 & 0,503 & $-0,010$ & $-0,243$ & $-2,047$ & 0,045 \\
\hline $\mathrm{F}$ & & 0,452 & & & & 4,191 & & \\
\hline Sig & & 0,503 & & & & 0,045 & & \\
\hline $\mathrm{R}$ & & 0,071 & & & & 0,243 & & \\
\hline $\mathrm{R}^{2}$ & & 0,005 & & & & 0,059 & & \\
\hline Variabel Terikat & \multicolumn{4}{|c|}{ Kepemilikan Individual } & \multicolumn{4}{|c|}{ Kepemilikan Institusional } \\
\hline
\end{tabular}

Sumber: Data diolah

keempat yaitu untuk menguji apakah perubahan peraturan perpajakan memoderasi kebijakan dividen terhadap kepemilikan individual dan institusional menggunakan moderated linier regression. Berdasarkan hasil pengolahan data dengan menggunakan uji regresi linier sederhana maka diperoleh hasil seperti pada Table 5 .

\section{Kebijakan Dividen Terhadap Kepemilikan Individual}

Pada Tabel 5 terlihat bahwa nilai koefisien determinasi $\left(\mathrm{R}^{2}\right)$ kepemilikan individual sebesar 0,005, hal ini menunjukkan bahwa kebijakan dividen berpengaruh terhadap kepemilikan individual $\left(\mathrm{Y}_{1}\right)$ sebesar 0,005 atau 0,5\% sedangkan sisanya sebesar 0,995 atau 99,5\% dipengaruhi oleh variabel lain diluar variabel bebas yang digunakan dalam penelitian. Hasil regresi tersebut menunjukkan bahwa kebijakan dividen berpengaruh positif terhadap kepemilikan individual dengan nilai koefisien 0,006. Signifikansi uji t kebijakan dividen sebesar 0,503, nilainya lebih besar dari 0,10, maka dapat disimpulkan bahwa "Kebijakan Dividen berpengaruh positif tetapi tidak signifikan terhadap Kepemilikan Individual" (menerima $\mathrm{H}_{0}$ dan menolak $\mathrm{H}_{1}$ ), sehingga hipotesis pertama tidak terbukti kebenarannya.

Berdasarkan hasil regresi, dapat diketahui bahwa variabel kebijakan dividen mempunyai pengaruh positif tetapi tidak signifikan terhadap kepemilikan individual. Ketidaksignifikannya pengaruh kebijakan dividen mengindikasikan bahwa kebijakan perusahaan untuk membayarkan dividen yang tinggi tidak akan mendorong peningkatan persentase kepemilikan saham individual secara signifikan di perusahaan tersebut. Sehingga hasil tersebut konsisten dengan teori yang dikemukakan Dividend Irrelevancy Theory (1961) yang menyatakan bahwa kebijakan dividen bersifat irrelevant karena tidak dapat mempengaruhi nilai perusahaan dan harga saham, sehingga investor dapat memodifikasi yields mereka tanpa terpengaruh oleh besarnya dividen.

Hasil penelitian ini tidak konsisten dengan penelitian yang dilakukan Nurwulandari (2008) dan Jain (2007) yang menghasilkan kesimpulan bahwa kepemilikan saham oleh individu lebih menyukai perusahaan yang membayar dividen yang tinggi, karena pembayaran dividen memiliki tingkat kepastian yang tinggi bila dibandingkan dengan capital gain (Bird in the Hand Theory). Ketidakkonsistenan ini disebabkan oleh karena hipotesis pertama dalam penelitian ini tidak memperhitungkan insentif pajak berupa perubahan peraturan perpajakan yakni penurunan dan penyederhanaan tarif pajak atas dividen yang diterima investor individu. Sehingga memenuhi salah satu asumsi dari teori Dividend Irrelevancy, yakni suatu pasar yang sempurna (tanpa pajak dan biaya kebangkrutan), investor bersifat rasional, dan adanya kepastian yang sempurna (perfect certainty).

\section{Kebijakan Dividen Terhadap Kepemilikan Institusional}

Pada tabel 5 terlihat bahwa nilai koefisien determinasi $\left(\mathrm{R}^{2}\right)$ kepemilikan institusional adalah sebesar 0,059, hal ini berarti bahwa kebijakan dividen berpengaruh terhadap kepemilikan institusional $\left(\mathrm{Y}_{2}\right)$ sebesar 0,059 atau 5,9\% sedangkan sisanya sebesar 0,941 atau 94,1\% dipengaruhi oleh variabel lain di luar variabel bebas yang digunakan dalam penelitian.

Hasil analisis regresi menunjukkan bahwa kebijakan dividen berpengaruh negatif terhadap kepemilikan institusional dengan nilai koefisien 0,006. Signifikansi uji t kebijakan dividen sebesar 0,045 , nilainya kurang dari 0,10 , maka dapat disimpulkan bahwa "Kebijakan Dividen berpengaruh negatif dan signifikan terhadap Kepemilikan Institusional" (menolak $\mathrm{H}_{0}$ dan menerima $\mathrm{H}_{1}$ ), sehingga hipotesis kedua terbukti kebenarannya. 
Hasil ini konsisten dengan teori yang dikemukakan oleh Dewi (2008) dan Jain (2007) yang menyatakan bahwa dengan adanya pembagian dividen yang tinggi, investor institusi menganggap manajer perusahaan tidak mampu melihat peluang-peluang investasi yang lebih menguntungkan. Kepemilikan institusional merupakan pemegang saham terbesar yang dapat berperan sebagai agen pengawas yang efektif untuk mengurangi agency problem, hal ini menyebabkan fokus utama dari investor institusi tidak pada memperoleh keuntungan berupa pembayaran dividen, namun cenderung kepada investasi-investasi lain yang lebih menguntungkan. Preferensi investor institusi lebih condong kepada alternatif yang memberikan manfaat yang lebih besar, dalam hal ini pada alternatif yang menawarkan tarif pajak paling rendah. Selain itu, pada umumnya kepemilikan institusional merupakan highertaxed institutional investor, sehingga investor institusi cenderung tidak menyukai pembayaran dividen yang tinggi, dan lebih menyukai capital gain karena tarif pajaknya jauh lebih rendah.

Langkah selanjutnya adalah menguji apakah perubahan peraturan perpajakan memoderasi kebijakan dividen terhadap kepemilikan individual dan institusional dengan menggunakan metode moderated linier regression. Berdasarkan hasil pengelolaan data maka diperoleh hasil perhitungan seperti pada Table 6 .

Perubahan Peraturan Perpajakan Memoderasi Pengaruh Kebijakan Dividen Terhadap Kepemilikan Individual

Pada Tabel 6 terlihat bahwa nilai koefisien determinasi berganda $\left(R^{2}\right)$ adalah sebesar 0,055, hal ini berarti bahwa kebijakan dividen dan interaksi kebijakan dividen dengan perubahan peraturan perpajakan berpengaruh terhadap kepemilikan individual $\left(\mathrm{Y}_{1}\right)$ sebesar 0,055 atau 5,5\% sedangkan sisanya sebesar 0,945 atau 94,5\% dipengaruhi oleh variabel lain di luar variabel bebas yang digunakan dalam penelitian. Sedangkan nilai $\mathrm{F}$ adalah 2,605 dengan tingkat signifikansi 0,080. Oleh karena tingkat signifikansi ini kurang dari 0,10 maka dapat disimpulkan bahwa kebijakan dividen (X) dan interaksi kebijakan dividen dan perubahan peraturan perpajakan $\left(\mathrm{X}^{*} \mathrm{Z}\right)$ secara bersama-sama berpengaruh signifikan terhadap kepemilikan individual. Selanjutnya dilakukan uji t yang menunjukkan bahwa interaksi antara kebijakan dividen dengan perubahan peraturan perpajakan mempunyai nilai t sebesar 2,177 dengan tingkat signifikansi 0,032, nilainya kurang dari 0,10 dan koefisien nilai t bertanda positif. Sehingga dari hasil tersebut dapat disimpulkan bahwa "Perubahan Peraturan Perpajakan memoderasi secara positif pengaruh Kebijakan Dividen terhadap Kepemilikan Individual”, sehingga hipotesis ketiga diterima kebenarannya.

Hasil ini konsisten dengan teori yang dikemukakan Clientele Effect Theory (1961) yang menyatakan bahwa kelompok investor yang berbeda akan memiliki preferensi yang berbeda terhadap kebijakan dividen Sehingga kebijakan dividen seharusnya ditujukan untuk memenuhi kebutuhan segmen investor tertentu. Untuk kelompok investor yang muncul akibat perbedaan pajak (Tax Differentiation Theory) cenderung menginginkan penghasilan dalam bentuk capital gain apabila lapisan tarif pajak yang dikenakan terkena lapisan tertinggi. Sebaliknya, kelompok investor yang terkena pajak rendah, umumnya terdiri dari investor individu, lebih menyukai pembayaran berupa dividen.

Dengan adanya perubahan Peraturan Perpajakan berupa penurunan dan penyederhanaan tarif pajak atas penghasilan dividen yang diterima oleh Wajib Pajak Orang Pribadi ini, semakin mendorong investor individu untuk menanamkan modalnya dalam bentuk kepemilikan saham perusahaan. Hal ini dibuktikan dengan adanya pengaruh secara positif dan signifikan dari kebijakan dividen terhadap kepemilikan individu-

Tabel 6. Hasil Uji Moderated Linier Regression terhadap $\mathrm{Y}_{1}$ dan $\mathrm{Y}_{2}$

\begin{tabular}{|c|c|c|c|c|c|c|c|c|}
\hline Variabel & $\begin{array}{c}\text { Koefisien } \\
\text { Regresi }\end{array}$ & Beta & $\mathbf{t}$ & Sig. & $\begin{array}{c}\text { Koefisien } \\
\text { Regresi }\end{array}$ & Beta & $\mathbf{T}$ & Sig. \\
\hline (Constant) & 0,067 & & 0,838 & 0,404 & $-0,015$ & & $-0,219$ & 0,827 \\
\hline Kebijakan Dividen & 0,030 & 0,042 & 0,408 & 0,684 & $-0,103$ & 0,216 & $-1,869$ & 0,066 \\
\hline $\mathrm{X} * \mathrm{Z}$ & 0,166 & 0,226 & 2,177 & 0,032 & $-0,127$ & $-0,256$ & $-2,215$ & 0,030 \\
\hline $\mathrm{F}$ & \multicolumn{4}{|c|}{2,605} & \multicolumn{4}{|c|}{4,670} \\
\hline Sig & \multicolumn{3}{|c|}{0,080} & & \multicolumn{4}{|c|}{0,013} \\
\hline $\mathrm{R}$ & \multicolumn{3}{|c|}{0,235} & & \multicolumn{4}{|c|}{0,352} \\
\hline $\mathrm{R}^{2}$ & \multicolumn{3}{|c|}{0,055} & & \multicolumn{4}{|c|}{0,124} \\
\hline Variabel Terikat & \multicolumn{3}{|c|}{ Kepemilikan Individual } & & \multicolumn{4}{|c|}{ Kepemilikan Institusional } \\
\hline
\end{tabular}


al dengan dimoderasi oleh Perubahan Peraturan Perpajakan. Sehingga kebijakan perusahaan untuk membayarkan dividen yang tinggi akan mendorong peningkatan persentase kepemilikan saham individual secara signifikan di perusahaan tersebut apabila dimoderasi dengan perubahan Peraturan Perpajakan berupa penurunan dan penyederhanaan tarif pajak atas penghasilan berupa dividen yang diterima oleh investor individu.

Hasil penelitian ini konsisten dengan penelitian yang dilakukan oleh Wu (1996), Korkeamaki et al. (2010) dan Zulaikah (2012). Menurut penelitian yang dilakukan oleh Wu (1996) dan Korkeamaki et al. (2010), Reformasi Pajak melalui perubahan tarif pajak telah memberikan dampak positif pada kebijakan dividen yang selanjutnya berpengaruh terhadap tingkat kepemilikan saham secara keseluruhan. Begitupula dengan hasil penelitian yang dilakukan oleh Zulaikah (2012) yang menunjukkan bahwa penurunan tarif pajak penghasilan dividen atas wajib pajak orang pribadi dalam negeri memoderasi pengaruh kepemilikan manajerial terhadap peningkatan kebijakan pembayaran dividen perusahaan.

\section{Perubahan Peraturan Perpajakan Memo- derasi Pengaruh Kebijakan Dividen Terhadap Kepemilikan Institusional}

Berbeda halnya dengan kepemilikan institusional yang memiliki nilai $\mathrm{R}^{2}$ sebesar 0,124 , hal ini berarti bahwa kebijakan dividen dan interaksi kebijakan dividen dengan perubahan peraturan perpajakan berpengaruh terhadap kepemilikan institusional $\left(\mathrm{Y}_{2}\right)$ sebesar 0,124 atau 12,4\% sedangkan sisanya sebesar 0,876 atau $87,6 \%$ dipengaruhi oleh variabel lain diluar variabel bebas yang digunakan dalam penelitian. Berdasarkan tabel 6, dapat terlihat bahwa nilai $\mathrm{F}$ adalah 4,670 dengan tingkat signifikansi 0,013. Oleh karena tingkat signifikansi ini kurang dari 0,10 maka dapat disimpulkan bahwa kebijakan dividen (X) dan interaksi kebijakan dividen dan perubahan peraturan perpajakan $\left(\mathrm{X}^{*} \mathrm{Z}\right)$ secara bersama-sama berpengaruh signifikan terhadap kepemilikan institusional. Selanjutnya dilakukan uji t yang menunjukkan hasil bahwa interaksi antara kebijakan dividen dengan perubahan peraturan perpajakan mempunyai nilai t sebesar 2,215 dengan tingkat signifikansi 0,030. Nilai signifikansi ini kurang dari 0,10 dan koefisien nilai t bertanda negatif, sehingga dari hasil ini dapat disimpulkan bahwa "Perubahan Peraturan Perpajakan memoderasi secara negatif pengaruh Kebijakan Dividen terhadap Kepemilikan Insti- tusional", sehingga hipotesis keempat diterima kebenarannya.

Hasil ini konsisten dengan penelitian yang dilakukan oleh Korkeamaki et al. (2010), Wu (1996), Chang dan Rhee (1999), serta teori yang dikemukakan Tax Differentiation Theory (1982) yang menyatakan bahwa sebaiknya dividen dibagikan dalam jumlah yang rendah agar dapat menghemat pajak. Karena pada umumnya pajak yang dikenakan terhadap dividen lebih tinggi daripada pajak yang dikenakan terhadap capital gain. Dengan adanya perubahan Peraturan Perpajakan ini, semakin mendorong investor institusi untuk mengalihkan kepemilikan institusinya dalam bentuk kepemilikan saham individu untuk mendapatkan insentif pajak berupa penurunan dan penyederhanaan tarif pajak. Sehingga kebijakan perusahaan untuk membayarkan dividen yang tinggi akan mendorong penurunan persentase kepemilikan saham institusi secara signifikan di perusahaan tersebut apabila dimoderasi dengan perubahan Peraturan Perpajakan. Faktor utama yang menyebabkan pengalihan kepemilikan saham pada perusahaan tersebut disebabkan oleh karena kebijakan right issue yang dimiliki oleh perusahaan, dimana perusahaan hanya diperbolehkan untuk menerbitkan saham yang telah disetujui dalam Rapat umum Pemegang Saham (RUPS) dan diprioritaskan untuk dijual kepada pemegang saham lama (preemptive right).

Selain itu, hal lain yang menjadi perhatian dalam penelitian ini adalah perbedaan tingkat sensitifitas peningkatan kepemilikan individual dengan penurunan kepemilikan konstitusional. Nilai koefisien peningkatan variabel kepemilikan individual dengan dimoderasi perubahan Peraturan Perpajakan menunjukkan koefisien sebesar 0,166, lebih besar dibandingkan koefisien penurunan variabel kepemilikan institusional dengan dimoderasi perubahan Peraturan Perpajakan, yakni sebesar 0,127. Hasil ini menunjukkan bahwa peningkatan variabel kepemilikan individual memiliki tingkat sensitifitas lebih besar dibandingkan penurunan variabel kepemilikan institusional dengan dimoderasi perubahan Peraturan Perpajakan. Hal ini disebabkan oleh karena adanya investor baru yang terdorong untuk menanamkan modalnya dalam bentuk kepemilikan saham individual dengan didukung oleh perubahan Peraturan Perpajakan, mengingat beban pajak atas penghasilan berupa dividen yang ditanggung oleh investor individu menjadi semakin ringan.

Selain itu penyebab lain yang mempengaruhi kondisi tersebut adalah karena beberapa dari investor institusi memiliki prosentase kepemilikan 
saham pada perusahaan lebih besar dari $25 \%$ dari jumlah modal yang disetor, sehingga termasuk ke dalam kriteria penghasilan dividen yang dikecualikan dari objek pajak (non taxable income), yang diatur di Pasal 4 ayat 3 huruf f angka 2 UU PPh. Karena alasan mendapatkan fasilitas pengecualian objek pajak atas penghasilan berupa dividen tersebut, beberapa investor institusi cenderung untuk enggan mengalihkan kepemilikan saham institusinya ke dalam bentuk kepemilikan individual, serta mendorong investor institusi untuk tetap berada di pasar modal dan tidak menarik investasinya pada perusahaan tersebut.

Hasil penelitian ini menunjukkan bahwa insentif pajak dengan cara menurunkan tarif pajak atas penghasilan berupa dividen untuk Orang Pribadi sebenarnya sudah cukup efektif, karena memberikan insentif agar investor individu dan investor institusi untuk tetap berada di pasar modal dan tidak menarik investasinya dari pasar modal Indonesia. Namun dari hasil analisis regresi menunjukkan bahwa nilai koefisien determinasi $\left(R^{2}\right)$ masih sangat rendah, sehingga kebijakan dividen yang dimoderasi oleh insentif pajak (tax incentive), bukan menjadi faktor utama yang menentukan preferensi investor untuk menanamkan modalnya di suatu perusahaan. Ada faktor faktor lain selain pajak (non tax incentive), seperti profitabilitas, investment opportunity, firm size, dan firm characteristic; yang mendorong investor untuk menanamkan atau menarik modalnya pada suatu perusahaan, meskipun pada faktanya faktor pajak tidak dapat dihindari, karena merupakan faktor tetap yang membatasi investor dalam berinvestasi.

\section{KESIMPULAN DAN SARAN}

\section{Kesimpulan}

Berdasarkan hasil analisis pada pembahasan, dapat disimpulkan sebagai berikut:

1. Kebijakan pembayaran dividen mempunyai pengaruh positif dan tidak signifikan terhadap kepemilikan saham individual. Karena tidak memperhitungkan insentif pajak berupa perubahan peraturan perpajakan, sehingga memenuhi salah satu asumsi dari teori Dividend Irrelevancy.

2. Kebijakan pembayaran dividen mempunyai pengaruh negatif dan signifikan terhadap kepemilikan saham institusional. Hal ini karena fungsinya sebagai agen pengawas yang efektif sehingga investor institusi lebih fokus kepada investasi yang lebih menguntungkan, mengingat tarif pajak dividen untuk investor institusi lebih tinggi jika dibandingkan dengan tarif pajak capital gain.
3. Perubahan Peraturan Perpajakan memoderasi secara positif dan signifikan pengaruh kebijakan pembayaran dividen terhadap kepemilikan saham individual. Perubahan peraturan perpajakan berupa penurunan dan penyederhanaan tarif pajak atas dividen mendorong investor individu untuk semakin menanamkan modalnya di pasar modal (Tax Differentiation Theory).

4. Perubahan Peraturan Perpajakan memoderasi secara negatif dan signifikan pengaruh kebijakan pembayaran dividen terhadap kepemilikan saham institusional. Karena investor institusi merupakan higher tax investor, sehingga Perubahan Peraturan Perpajakan mendorong investor institusi untuk mengalihkan kepemilikan sahamnya ke kepemilikan dalam bentuk individual.

5. Perubahan Peraturan Perpajakan akan mendorong perusahaan untuk membayarkan dividen dalam jumlah yang cukup besar, sehingga mendorong investor baru untuk menanamkan modalnya dalam bentuk kepemilikan saham individual.

6. Fasilitas pengecualian objek pajak atas penghasilan berupa dividen yang diterima oleh investor institusi membuat investor institusi cenderung untuk enggan mengalihkan kepemilikan saham institusinya ke dalam bentuk kepemilikan individual, serta mendorong investor institusi untuk tetap berada di pasar modal dan tidak menarik investasinya pada perusahaan tersebut.

\section{Saran}

1. Perusahaan sebaiknya melakukan evaluasi terhadap kebijakan pembayaran dividen dengan mempertimbangkan faktor perpajakannya. Dengan adanya keuntungan berupa penurunan dan penyederhanaan tarif pajak atas dividen yang diterima investor individu, diharapkan mendorong perusahaan untuk meningkatkan pembayaran dividen sehingga dapat menginsentif investor domestik dan asing untuk semakin menanamkan modalnya di pasar modal Indonesia.

2. Bagi investor dan calon investor, dalam rangka menanamkan modalnya, diharapkan dapat lebih memperhatikan efek perpajakannya. Sehingga dapat memanfaatkan keringanan tarif pajak atas dividen yang diterima oleh investor individu.

3. Pemerintah sebaiknya mengevaluasi kembali perubahan peraturan perpajakan yang telah direalisasi, meskipun insentif pajak dengan cara menurunkan tarif pajak dividen yang 
diterima investor individu sebenarnya sudah cukup efektif, namun belum menjadi faktor utama dalam peningkatan investasi di pasar modal Indonesia. Hal ini karena tarif pajak atas dividen masih jauh lebih tinggi bila dibandingkan dengan tarif pajak atas investasi lainnya, seperti capital gain.

4. Nilai koefisien determinasi yang masih rendah dalam penelitian ini hendaknya dijadikan pertimbangan oleh peneliti berikutnya untuk menggunakan faktor-faktor kontrol yang lain seperti profitabilitas, firm size, dan firm characteristic untuk menjelaskan pengaruh kebijakan dividen terhadap kepemilikan individual dan institusional.

\section{DAFTAR PUSTAKA}

Bathala, et al. (1994). Managerial Ownership, Debt Policy, and The Impact of Institutional Holding: An Agency Perspective. Financial Management, 38-50.

Brennan, M. J. and Thakor, A. V. (1990). Shareholder Preferences and Dividend Policy. The Journal of Finance, 993-1018.

Chang, R. P. and Rhee, S. G. (1990). The Impact of Personal Taxes on Corporate Dividend Policy and Capital Structure Decision. Journal Finance and Economic, 21-31.

Cooper, D. R. and Emory, C. W. (1995). Business Research Method. US: Irwin.

CPA Institute. (2007). Managing Investments Portofolios: A Dinamic Process, Third Edition, New Jersey: John Wiley \& Sons. Inc.

Dewi, S. C. (2008). Pengaruh Kepemilikan Manajerial, Kepemilikan Institusional, Kebijakan Hutang, Profitabilitas, dan Ukuran Perusahaan terhadap Kebijakan Dividen. Jurnal Bisnis dan Akuntansi, 10(1), 47-58.

Direktorat Riset Ekonomi dan Kebijakan Moneter. (2012). Outlook Ekonomi Indonesia: Krisis Finansial Global dan Dampaknya terhadap Perekonomian Indonesia. http://www.bi.go.id/ web/id/Publikasi/Kebijakan+Moneter/Outlook +Ekonomi+Indonesia/oei_0109.html

Hair, J. F. (2010). Multivariate Data Analysis, New Jersey: Pearson Prentice Hall.

Hanafi, M. M. (2004). Manajemen Keuangan, Yogyakarta: BPFE UGM.

Horne, J. C. and Wachowicz, J. M. (2012). PrinsipPrinsip Manajemen Keuangan, Edisi Ke-13, Jakarta: Penerbit Salemba Empat.
Jain, R. (2007). Institutional and Individual Investor Preferences from Dividends and Share Repurchase. Journal of Economics and Business, 406-426.

Korkeamaki, et al. (2010). Tax Reform and Payout Policy: Do Shareholder Clienteles or Payout Policy Adjust?. Journal of Corporate Finance, 572-587.

Litzenberger, R. H. and Ramaswamy, K. (1979). "The Effect of Personal Taxes and Dividends on Capital Asset Prices: Theory and Empirical Evidence. Journal of Financial Economics, 163-195.

Miller, M. H. and Modigliani, F. (1961). Dividend Policy, Growth, and The Valuation of Shares. The Journal of Business, 411-433.

Norr, M. (1982). The Taxation of Corporation and Shareholders. Netherland: Deventer Kluwer Law and Tax Publisher.

Nurwulandari, A. (2003). Analisis Hubungan Antara Kepemilikan Saham Minoritas dan Dividend Payout Ratio dengan Laba dan Investment Opportunity Set Sebagai Variabel Moderasi. Skripsi Universitas Nasional, Fakultas Ekonomi. Jakarta.

Peraturan Menteri Keuangan Nomor 111/PMK.03/ (2010). Tentang Tata Cara Pemotongan, Penyetoran, dan Pelaporan Pajak Penghasilan atas Dividen yang Diterima atau Diperoleh Wajib Pajak Orang Pribadi Dalam Negeri.

Peraturan Pemerintah Nomor 41 Tahun 1994, Tentang Pajak Penghasilan atas Penghasilan dari Transaksi Penjualan Saham di Bursa Efek.

Peraturan Pemerintah Nomor 14 Tahun 1997, Tentang Pajak Penghasilan atas Penghasilan dari Transaksi Penjualan Saham di Bursa Efek.

Peraturan Pemerintah Nomor 19 Tahun 2009, Tentang Penyampaian Peraturan Pemerintah Nomor 19 Tahun 2009 tentang Pajak Penghasilan Atas Dividen yang Diterima atau Diperoleh Wajib Pajak Orang Pribadi Dalam Negeri.

Republik Indonesia, Undang-Undang Nomor 17 Tahun 2000 tentang Perubahan Ketiga atas Undang-Undang Nomor 7 Tahun 1983 Tentang Pajak Penghasilan.

Republik Indonesia, Undang-undang Nomor 36 Tahun 2008 tentang Perubahan Ketiga atas Undang-Undang Nomor 7 Tahun 1983 Tentang Pajak Penghasilan. 
Sartono, A. (2001). Manajemen Keuangan Teori dan Aplikasi. Yogyakarta: BPEF-Yogyakarta.

Scott, D. L. (2003). Wall Street Words: An A to $Z$ Guide to Investment Terms for Today's Investor. Third Edition, Boston: Houghton Miffin Company.

Sponholtz, C. (2005). Separating The Stock Market's Reaction to Simlutnaeous Dividend and Earnings Announcements, Working Paper, Denmark University of Aarhus.
Wu, C. (1996). Taxes and Dividend Policy, International Review of Economics and Finance, page 291-305.

Zulaikah, N. (2012). Pengaruh Kepemilikan Manajerial terhadap Kebijakan Pembayaran Dividen Perusahaan dan Penurunan Tarif Pajak Penghasilan Dividen Orang Pribadi Dalam Negeri sebagai Variabel Moderator. Tesis: Universitas Airlangga, Fakultas Ekonomi dan Bisnis, Surabaya. 